\title{
NILAI BUDAYA BANGUNAN DAN RAGAM HIAS CANDI KEMBAR BATU MUARA JAMBI SEBAGAI SUMBER PEMBELAJARAN SEJARAH DI SMA AZHARYAH PALEMBANG
}

\author{
Oleh: *Fitria Larasati \\ *Mahasiswa Program Studi Pendidikan Sejarah Universitas PGRI Palembang
}

\begin{abstract}
ABSTRAK
Candi Kembar Batu Muara Jambi memiliki nilai sejarah yang tinggi serta meninggalkan banyak peninggalan-peninggalan kebudayaan. nilai budaya bangunan terdapat pada fungsi dari candi itu sendiri sedangkan ragam hias ditemukannya relif bentuk stupa pada bagian depan gapura atau pintu gerbang candi. Permasalahan pada penelitian ini adalah bagaimanakan nilai budaya bangunan dan ragam hias candi Kembar Batu Muara Jambi dapat dijadikan sebagai sumber pembelajaran sejarah? tujuan penelitian yaitu untuk mengetahui nilai budaya banguna dan ragam hias candi Kembar Batu Muara Jambi. Metode yang digunakan dalam penelitian ini ialah metode penelitian deskriptif kualitatif dengan menggunakan cara pengumpulan sumbersumber secara sistematis dan menggunakan sumber data secara mendalam. Tenik pengumpulan data dilakukan dengan tiga cara yakni dokumentasi, wawancara, dan observasi. Minimal ada tiga hal yang digambarkan dalam penelitian kualitatif yaitu, karakteristik pelaku, kegiatan atau kejadian-kejadian yang terjadi selama penelitian berlangsung, dan keadaan lingkungan atau karakteristik tempet penelitian kualitatif. Hasil penelitian: Nilai budaya pada bangunan candi Kembar Batu Muara Jambi terletak pada fungsi candi itu sendiri yang mana candi kemudian dikaitkan dengan bangunan kematian atau pemujaan arwah, Sedangkan ragam hias yang terdapat pada candi Kembar Batu sendiri adalah adanya relif berbentuk stupa yang terletak pada bagian depan gapura atau pintu gerbang candi. Stupa merupakan salah satu dari objek religius terpenting agama Buddha karena stupa dianggap sebagai gambaram makrokosmos yang berkaitan dengan sang Buddha.
\end{abstract}

Kata Kunci: Nilai Budaya Banguna, Ragam Hias, Candi Kembar Batu, Sumber Pembelajaran Sejarah

\section{A. PENDAHULUAN}

Provinsi Jambi yang terdiri dari enam daerah tingkat II, yaitu Kotamadya Jambi, Kabupaten Batang Hari, Kabupaten Sarobangun Sangko, Kabupaten Bungo Tubo, Kabupaten Tanjung Jabung, dan Kabupaten Kerinci. Terbagi menjadi 37 kecamatan dengan 1292 desa, luas 53.244 $\mathrm{km}^{2}$. Secara Topografis ia dapat dibagi atas tiga daerah yaitu daerah Pantai, daerah Dataran dan daerah dataran Tinggi (Wiyoso, 1982:1).

Situs Muara Jambi terletak di Desa Muara Jambi, Kecamatan Marosebo, Kabupaten Muara Jambi, sekitar 30 km dari Kota Jambi. Desa Muara Jambi ini merupakan desa yang memiliki bentang alam yang dibelah oleh aliran sungai Batanghari yang melewati wilayah desa ini. Secara astronomis desa ini berada pada 103022' BT hingga $103^{\circ} 45^{\prime}$ BT dan 1024' LS hingga 1033' LS. secara keseluruhan wilayah desa Muara Jambi berada pada ketinggian 8 hingga 12 meter dari permukaan laut. Berdasarkan ketinggian ini lingkungan alam Desa Muara Jambi merupakan dataran rendah. Dilihat secara keseluruhan berada di daerah kawasan dataran rendah hutan tropis Sumatera.

Situs Muara Jambi ini adalah sebuah situs kompleks percandian yang merupakan tinggalan kebudayaan klasik masa Sriwijaya dan Melayu Kuno yang dipergunakan dalam masa yang cukup panjang sejak awal 7 
hingga $15 \mathrm{M}$, sebagimana dikutip dari sumber sejarah kekaisaran Cina dan Kerajaan Majapahit yang berpusat di Jawa Timur. Kompleks percandian Buddhis ini kemungkinan pernah dikunjungi pendeta Itsing pada tahun $671 \mathrm{M}$, yaitu ketika ia singgah di She-li-fo-she (Srivijaya) dan Molo-yeu untuk mendalami bahasa Sansekerta selama beberapa bulan sebelum berangkat ke Nalanda- India. Para Arkeolog yang terus bekerja dan menggali sisa-sisa reruntuhan candi memperkirakan tak kurang dari 82 reruntuhan bangunan suci Buddhis masih bisa dijumpai di areal seluas 2062 hektar. Dengan luas wilayah tesebut, maka Situs Muara Jambi merupakan suatu kompleks percandian terluas di Indonesia, yang keadaan bangunannya relatif masih utuh dan belum mengalami banyak bangunan sehingga mengakibatkan kerusakan terutama oleh aktivitas manusia (Purwanti, 2009:1).

Candi adalah salah satu peninggalan budaya dari zaman purba di Indonesia. Di Provinsi Jambi terdapat Candi Muara Jambi yang berlokasi di Kabupaten Muaro Jambi. Kebudayaan yang melatar belakangi Situs $S$ ejarah Muara Jambi ialah kebudayaan Melayu Budhis. Sedangkan Kerajaan tua ya ng diyakini berpusat di Muara Jambi ialah kerajaan Mo-lo-yeu (Melayu) dan Sriwijaya Situs Muaro Jambi lebih dikenal dengan sebutan Komplek Percandian Muara Jambi. Pada tahun 1976 Direktorat Sejarah dan Purbakala mulai melakukan pembersihan terhadap tanaman-tanaman liar yang tumbuh diatas bangunan kuno secara berta hap, sampai tahun 2003 telah teridentifikasi +110 bangunan candi baik yang telah dipug ar, belum dipugar maupun masih dalam bentuk manapo (Wiyoso, 1982:76).

Berdasarkan uraian diatas, peneliti bermaksud untuk melakukan penelitian dengan judul "Nilai Budaya Bangunan Dan Ragam Hias Candi Kembar Batu Muara Jambi Sebagai Sumber Pembelajaran Sejarah".

\section{B. METODE PENELITIAN}

Dalam penelitian ini peneliti menggunakan metode penelitian deskriptif kualitatif , yang menggunakan cara mengumpulkan sumber-sumber secara sistematis dan menggunakan sumber data secara mendalam. Berdasarkan rumusan masalah, peneliti mendeskripsikan mengenai Candi Kembar Batu Muara Jambi sebagai sumber pembelajaran sejarah di SMA Azharyah Palembang. Untuk memahami hal tersebut, dilakukan penelitian mengenai nilai budaya bangunan dan ragam hias Candi Kembar Batu Muara Jambi yang dapat dijadikan sebagai sumber pembelajaran sejarah.

\section{Data dan Sumber Data}

Data dan sumber data dalam penelitian ini adalah

a. Informan/Narasumber dalam penelitian ini adalah Ibu Nurhayati selaku pengurus Candi Kembar Batu, dan Ibu Martini, S.Pd selaku guru sejarah di SMA Azharyah Palembang.

b. Buku-buku yang relevan mengeni Candi Kembar Batu Muara Jambi dan silabus sejarah kelas $X$ SMA Azharyah Palembang.

c. Observasi lapangan dilakukan di Candi Kembar Batu Muara Jambi dan SMA Azharyah Palembang.

\section{Teknik Pengumpulan Data}

Teknik pengumpulan data yang peniliti gunakan yaitu sebagai berikut:

1. Dokumentasi

Dalam penelitian ini dokumentasi dilakukan di Komplek Candi Kembar Batu Muara Jambi dan di kelas $X$ SMA Azharyah Palembang tahun ajaran 2016/2017.

2. Observasi

Observasi dilakukan di Candi Kembar Batu Muara Jambi dan di kelas $X$ SMA Azharyah Palembang. 
3. Wawancara

Dalam penelitian ini peneliti melakukan wawancara kepada ibu Nurhayati selaku pengurus Candi Kembar Batu dan inu Martini, S.Pd selaku guru sejarah di SMA Azharyah Palembang.

\section{Teknik Keabsahan Data}

Peneliti menjelaskan bagaimana proses dan teknik yang digunakan untuk memeriksa keabsahan data. Uji keabsahan data dalam penelitian kualitatif meliputi uji Kredibility (validitas internal), transferability (validitas eksternal), dependability (reliabilitas), dan confirmability (obyektivitas) (Sugiyono, 2008:366).

\section{Teknik Analisis Data}

Teknik analisis data dalam penelitian kualitatif ke dalam tiga tahap yaitu: kodifikasi data/reduksi data, penyajian data, dan penarikan kesimpulan/verivikasi.

\section{HASIL DAN PEMBAHASAN Candi Kembar Batu Muara Jambi Letak Candi Kembar Batu}

Desa Muara Jambi merupakan daerah yang menjadi pusat dari adat dari marga Marosebo. Marga Marosebo adalah kelompok masyarakat yang merupakan penduduk asli yang telah menempati wilayah ini dan Marosebo saat ini menyebar di beberapa kampung asli yang pada saat ini berbentuk desa. Beberapa kampung asli itu antara lain Kunangan, Talang Duku, Tebat Patah, Kemingking Dalam, Teluk Jambu, Duson Mudo, Sekumbung dan Muara Jambi. Desa Muara Jambi merupakan desa yang memiliki bentangan alam dibelah oleh aliran sungan Batanghari yang melewati wilayah desa ini. Secara astronomis desa ini berada pada $103^{\circ} 22^{\prime}$ BT hingga $103^{\circ} 45^{\prime}$ BT dan 10 24' LS hingga $1033^{\prime}$ LS (Mundardjito, 2009:8).

Situs Muara Jambi adalah suatu wilayah berisi temuan purbakala di daerah Muara Jambi, yang membentang sepanjang lebih kurang tujuh kilometer, dengan Bukit Sengalo berada di ujung barat dan Manopo Buluran Dalam di ujung sebelum tidur. Batas sebelah utaranya rawa-rawa, dan batas selatannya adalah Sungai Batanghari. Di daerah sepanjang tujuh kilometer inilah nenek moyang kita diduga bertempat tinggal dan melakukan kegiatan mereka ratusan tahun yang lalu. Sisa-sisa kegiatan berupa reruntuhan bangunan atau akumulai benda peninggalan purbakalanya dijadikan pedoman dalam menentukan besaran situs. Hampir semua kompleks memiliki sebuah bangunan induk, perwara, gapura, dan pagar keliling termasuk di dalamnya kelengkapan bangunan berupa lantai bata dan beberapa ruas parit juga dibangun di sekitar kompleks untuk menghindari banjir yang tampaknya sering melanda Muara Jambi sejak dulu, dimana tanah hasil galian parit tersebut dipergunakan juga untuk meninggikan halaman candi agar kompleks terbebas dari genangan.

Situs percandian Muara Jambi memiliki luas sekitar 11 kilometer persegi. Hingga saat ini, di Area situs terdapat sekurang-kurangnya 82 buah sisa bangunan bata. Sebagian dari bangunan-bangunan bata tersebut mengelompok disuatu tepat yang dikelilingi tembok pagasr keliling, misalnya candi Teluk (di sebrang selatan Sungai Batanghari), Kembar Batu, Gedong, Gumpung, Tinggi, Kota Mahligai, dan Kedaton. Dan sebagian lagi merupakan suatu bangunan tersendiri yang letaknya terpisah-pisah, misalnya candi Astano, Manopo Melayu, dan beberapa Manopo kecil lainnya (Utomo, 2011:135-137).

Perhatian terhadap kepurbakalaan yang terdapat di Muara Jambi sudah dimulai sejak tahun 1820 oleh Kapten S.C. Crooke, seorang perwira kehormatan bangsa Inggris. Kemudian oleh Adam tahun 1920 melihat tinggalan di Muaro Jambi, ia menyimpulkan bahwa Muara Jambi merupakan sebuah ibu kota dengan bangunan-bangunan yang dibuat dengan batu/bata. Dugaan Adam ini disetujui oleh 
Schnitger yang berkunjung pada tahun 1936 (1937:5-9). Setelah lama tidak diteliti, pada tahun 1954 sebuah tim dari dinas purbakala menuju lokasi situs dan mendata kembali apa yang telah dilaporkan oleh Schnitger (1955:12-33). Pada tahun 1975 sampai sekarang Direktorat Perlindungan dan Pembinaan Peninggalan Sejarah dan Purbakala melakukan pemugaran pada candi Tinggi, Gumpung, Astano, Kembar Batu, Gedong I dan II, dan candi Kedaton. Kecuali candi Kedaton, pemugaran candicandi lain telah selesai dikerjakan. Sementara itu, Pusat Penelitian Arkeologi Nasional Sejarah tahun 1978 hingga sekarang secara periodik masih melakukan penelitian Arkeologi. Untuk menuju situs percandian Muara Jambi dapat menggunakan jalur darat. Ada dua pilihan rute darat yaitu (1) kota Jambi - jembatan Batanghari I-jalan lintas timur Sumaterasimpang setiris-desa Muara Jambipercandian Muara Jambi dan (2) kota Jambi-Talang Duku-desa Muara Jambi seberang-menyebrangi sungai Batangharidesa Muara Jambi-percandian Muara Jambi. Untuk rute pertama, kondisi jalan raya lebar dan mulus hanya dapat dinikmati sampai simpang setiris. Sesudah itu kondisi jalan yang sempit dan berlubang sampai ke komplek situs. Rute kedua, hanya dapat digunakan oleh sepeda motor karena tidak ada jembatan untuk menyebrang sehingga menggunakan rakit untuk mengangkut kendaran.

\section{Candi Kembar Batu}

Kompleks Candi Kembar batu terletak 250 meter di sebelah tenggara Candi Tinggi, tepatnya pada titik koordinat 01028 '39,7" LS dan 103040'15.2" BT, sedangkan luas lahan Candi Kembar batu adalah $59 \mathrm{~m}$ x $63 \mathrm{~m}$, tinggi halaman candi sekitar 2,5 meter dari permukaan tanah sekitarnya. Ekskavasi yang dilakukan membuktikan bahwa tanah untuk meninggikan halaman candi diperoleh dari hasil galian parit. Kompleks Candi Kembar batu dipugar pada tahun 1994-
1995, telah menampakkan antara lain: 1 bangunan induk, 5 perwara yang telah dipugar, 2 perwara yang belum dipugar, 2 struktur bangunan yang belum diketahui fungsinya, pagar keliling, gapura dan parit keliling yang lebarnya sekitar 3 meter. Bangunan induk candi ini berdenah segi empat dengan ukuran 11,39 m x 11,33 m. Pintu masuknya terletak di sisi timur berhadapan dengan bangunan perwara I. Pada bagian atas kaki bangunan terdapat lubang yang jumlahnya 12 buah. Lubanglubang ini diduga dipakai untuk menancapkan tiang kayu sebagai penyangga atap bangunan. Bangunan perwara memiliki tangga naik disisi barat dan timur Arah hadap bangunan induk menghadap ke timur, struktur I menghadap ke timur-barat, struktur II dan V menghadap ke timur dan struktur III dan IV menghadap ke utara. Selain bangunan, di kompleks Candi Kembar batu juga terdapat temuan berupa gong yang terbuat dari perunggu bertulis huruf Cina, lempengan-lempangan emas, batu mulia, bata bertuliskan huruf jawa kuno serta keramik Cina sekitar abad 10 m-12 m (Hasil observasi candi Kembar Batu tanggal 20 Maret 2017).

Kompleks Candi Kembar Batu terletak sekitar 250 meter di sebelah tenggara Candi Tinggi. Kompleks Candi Kembar Batu seluruh strukturnya terbuat dari bata. Pada tahun 1994 seluruh kompleks bangunan telah selesai dipugar, kecuali dua buah bangunan perwara karena alasan teknis tidak dilakukan pemugaran namun pondasi asli yang masih terpendam di dalam tanah. Kompleks Candi Kembar Batu terdiri dari pagar keliling dan gapura, candi induk, perwara, dan dua struktur bangunan lain yang belum diketahui fungsinya.

Ekskavasi yang dilakukan pusat penelitian Arkeologi Nasional pada tahun 1982 dan 1983 dekat candi berhasil menemukan banyak pecahan keramik lokal maupun asing dari bentuk kendi, cawan, periuk, pasu, tutup, dan tungku. Keramik 
asing pada umumnya berasal dari masa Dinasti Sung (abad ke 13-14) di Cina. Selain itu pada halaman dalam kompleks candi terdapat bekas lantai bata yang telah dipadatkan dengan hancuran bata. Sewaktu dilakukan pemugaran kompleks candi pada tahun 1994, pada salah satu bangunan perwara yaitu perwara 3 ditemukan artefak berupa lempengan emas sebanyak 12 buah. Lempengan emas tersebut berukuran sama panjang antara 4,3-4,5 cm dan lebar antara 1,6-2,4 cm. Lempengan dalam kondisi utuh ini tidak memiliki tulisan ataupun gambar dan ditemukan dibawah lapisan bata berhias lotus. Bersamaan dengan lempengan emas juga didekatnya ditemukan sejumlah batu akik berwarna putih, merah, dan biru dengan tebal antara $0.1-0,5 \mathrm{~cm}$ dan panjang antara $0,35-1 \mathrm{~cm}$.

\section{Nilai Keagamaan Candi Kembar Batu}

Dengan memperhatikan temuantemuan arca yang terdapat di derah pedalaman Jambi, (kabupeten Sarko dan Bungo-Tebo) dan percandian di kabupaten Batanghari (antara lain Muaro Jambi dan sekitarnya), jelas bahwa daerah Jambi ini di zaman purba merupakan wilayah yang masyarakatnya penganut agama dan kebudayaan Budha. Hutan belantara yang masih menyelimuti sebagian besar wilayah propinsi Jambi ini, mungkin sekali juga berfungsi menyelimuti sejumlah teka-teki sejarah yang berhubungan dengan kebesarab Sriwijaya dan Melayu. Jawaban atas teka-teki itu hanya mungkin diberikan oleh hasil penelitian arkeologi di dalam hutan belantara dimaksud. Beberapa temuan yang ada hanyalah merupakan isyarat atas kemungkinan banyaknya benda-budaya dimaksud (Nazir, 1980/1981:17).

Ajaran Budha meluas pemeluknya terjadi pada abad ke-7-10 Masehi. Pada waktu itu sebuah kerajaan yang kuat dan perpengaruh di Asia Tenggara adalah Sriwijaya.kerajaan ini selain dikenal sebagai kerajaan maritim, juga dikenal sebagai kerajaan yang andilnya cukup besar dalam perkembangan ajaran Budha. Biksu Budha dari berbagai bangsa datang ke Sriwijaya untuk mempelajari tata-bahasa Sansekerta sebelum melanjutkan pelajarannya ke Nalanda di India. Bahkan Atisa, seorang biksu Budhadari Tibet menyempatkan diri untuk memperdalam ajaran Budha di Sriwijaya. Pada saat ini Budha Mahayana perkembangannya cukup pesat. Wilayah penyebarannya di Sumatera, Jawa, Kalimantan (Barat dan Timur), Sulawesi (Selatan dan Barat), Bali, dan Nusatenggara Barat. Sumatera dan Jawa dapat dikatakan pusat ajaran ini berkembang. Banyak monumen Budha Mahayana yang dibangun oleh penguasa-penguasannya. Monumen yang ada di Jawa dan Sumatera sebagian besar yang ditemukan dan masih berdiri merupakan pusat upacara. Untuk Muara Jambi para pengelola bangunan suci diduga bertempat tinggal ditepian sungai. Data arkeologis menunjukkan pada kita, di tepian sungai ini ditemukan sisa barang kebutuhan sehari-hari seperti keramik dan tembikar. Mereka membangun tempat tinggalnya berupa rumah-rumah yang dibangun di atas tiang. Persoalannya, di mana mereka bercocok tanam karena tidak mungkin para biksu dan biksuni hidup dari menangkap ikan di sungai dan mangkonsumsinya (Utomo, 2011:37).

Muara Jambi merupakan kompleks bangunan Budha Mahayana. Para penziayah datang untuk melakukan upacara. Diduga para penziarah itu datang dan bermalam dibagian luar tembok keliling bangunan suci. Ekskavasi arkeologi yang dilakukan dibagian luar tembok keliling banyak menemukan Anglo berbentuk sepatu. Anglo jenis ini biasa di bawa-bawa. Dihalaman luar bangunan kedaton ditemukan sebuah belanga berukuran besar dengan garis tengah sekitar 1 meter, dan dibuat dari bahan perunggu. Belanga ini biasa dipakai untuk memasak dalam volume yang besar mungkin saja dipakai ketika di Muara Jambi sedang berlangsung upacara 
besar, seperti peringatan hari Trisuci Waisak. Kompleks Muara Jambi kini dimanfaatkan kembali oleh umat Budha dari daerah Jambi. Tidak tertutup kemungkinan umat Budha dari tempat lain di Sumatera maupun luar Sumatera (Utomo, 2011:3637).

\section{Nilai Budaya Bangunan Candi Kembar Batu}

Candi diartikan sebagai bangunan kuno yang dibuat dari batu, berupa tempat pemujaan atau penyimpanan abu zenajah raja-raja atau pendeta-pendeta Hindu dan Budha. Dalam bahasa Sansekerta candi adalah sebutan untuk Durga atau dewi maut candika, sedangkan candi Greha atau candi Kgrha atau candi Kalaya adalah penamaan tempat pemujaan bagi dewi tersebut. Candi kemudian dikaitkan dengan bangunan kematian atau pemujaan arwah (candi Kalaya) dalam bahasa Jawa kuno. Candi atau cinandi atau sucandi berarti yang dikuburkan, sedangkan dalam pemahaman arkeologi, candi dapat dihubungkan dengan bangunan untuk pemakaman maupun pemujaan. Dalam prasasti prambanan, istilah candi dapat dikaitkan dengan graha (tempat) yakni Siwa graha (tempa tinggal Siwa-candi siwa prambanan). Menurut Sumalyo (1992:1) dalam Setyawan Dalam ilmu arsitektur candi adalah kaya arsitektur pada masa lalu yang memberikan informasi mengenai seni, teknik, tata ruang, geografi, dan sejarah. Dengan mempelajari candi akan dapat ditelaah lebih jauh mengenai konstruksi, struktur, bentuk bangunan, tata ruang dan proses perancangan arsitekturnya. Hal ini dikarenakan, dari segi tata ruang, arsitektur adalah pemenuhan, kebutuhan ruang oleh manusia atau kelompok manusia untuk melaksanakan aktivitas tertentu. Sedangkan dari segi sejarah, kebudayaan dan geografi, arsitektur adalah ungkapan fisik dan peninggalan budaya dari suatu masyarakat dalam batasan tempat dan waktu tertentu (Darwanto, 2001:33).

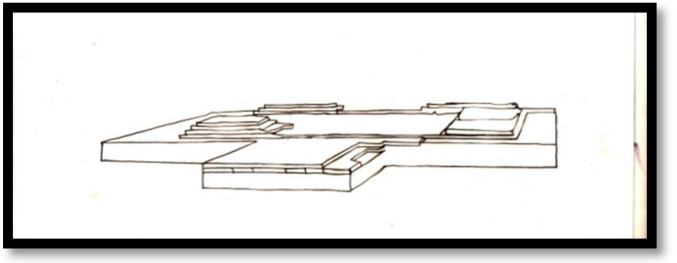

(Gambar: perwara ke IV Candi Kembar Batu Muara Jambi, sumber hasil gambar Okta Pranata)

Karya arsitektur senantiasa mengalami perkembangan dari masa ke masa, perubahan bentuk dapat dibedakan dalam dua hal, yang pertama perubahan secara perlahan-lahan atau revolusioner, yang kedua adalah secara cepat, yang digolongkan pada kategori pertama adalah arsitektur tradisonal yang berkembang dan mengalami perubahan dalam waktu berpuluh-puluh tahun bahkan beratus-ratus tahun. Sedangkan yang kedua adalah arsitektur modern, yang berkembang dan berubah dengan cepat sejalan dengan cepatnya perkembangan teknologi dan penduduk. Salah satu benda peninggalan masa lampau yang dapat digunakan sebagai alat untuk mengetahui kehidupan masa lampau adalah relief candi. Relief candi dapat menceritakan berbagai hal tentang kehidupan, yang dapat dikaji keberlanjutannya pada masa kini. Salah satu komponen yang terdapat pada relief candi Borobudur adalah penggambaran bangunan. Relief dengan gambar bangunan rumah cukup banyak ditemukan dan gambar-gambar tersebut dapat memberikan informasi tentang bentuk-bentuk rumah pada masa pembangunan candi tersebut serta kehidupan masyarakat di masa lalu. Relief dengan gambar bangunan rumah dapat ditemui di kaki candi pada panil-panil relief Karmawibhangga, serta pada dinding galeri-galeri candi.Jenis bangunan yang digambarkan pada panil-panil relief candi adalah bangunan dengan material batu dan bangunan dengan material kayu. Bangunan dengan material batu terutama adalah bangunan-bangunan pemujaan, sedangkan bangunan dengan material kayu adalah 
bangunan tempat tinggal atau rumah. Penelitian ini memberi perhatian pada reliefrelief yang menggambarkan bangunanbangunan kayu, karena penelitian ini ingin mengetahui kemenerusan bentuk-bentuk bangunan dari dulu sampai saat ini, dan bangunan kayu mkhususnya rumah kayu merupakan jenis bangunan yang masih banyak ditemukan di kawasan perdesaan sampai saat ini (Darwanto, 2011:33).

\section{Ragam Hias Candi Kembar Batu}

Ragam hias hadir di tengah-tengah kehidupan masyarakat sebagai media ungkapan perasaan yang diwujudkan dalam bentuk visual, yang proses penciptaannya tidak lepas dari pengaruh-pengaruh lingkungan. la ditujukan sebagai pelengkap rasa estetika. Rupanya didalam bentuk ragam hias itu terdapat pula makna simbolik tertentu menurut apa yang berlaku syah secara konvensional, dilingkungan masyarakat pendukungnya masa lampau telah memberikan kepada kita suatu gambaran tentang apa dan dimana karyakarya itu berada serta dibuat secara pribadi atau oleh masyarakat bahkan juga mengapa ia muncul (Toekio,1987: 9-10).

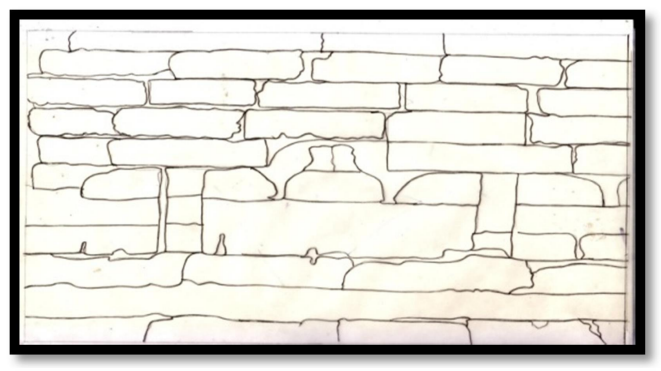

(Gambar: Relif stupa yang menjadi ragam hias yang ditemukan di gapura Candi Kembar Batu Muara Jambi, sumber hasil gambar Futria Larasati)

Ragam hias pada suatu benda pada dasarnya merupakan pedandan (make up) yang diterapkan guna mendapatkan keindahan atau kemolekan yang dipadukan. Ragam hias itu berperan sebagai media untuk mempercantik atau menganggunkan suatu karya. Berbicara tentang ragam hias, tentunya tidak lepas dari unsur-unsur apa yang menjadi pendukung terjadinya bentukbentuk visual tersebut. Dalam hal ini unsur visual sangat besar artinya. Disini kita akan menemukan peran garis, bidang, tekstur bahkan juga warna. Pada ragam hias benda tiga dimensi dapat kita temukan bentukbentuk bidang yang mempunyai sifat lekuk atau menonjol. Kedua keadaan ini dapat kita katakan sebagai sifat yang positif: yakni yang kita lihat menonjol atau menjorok dari permukaan bendanya, serta negatif dari beberapa bentuk yang lekuk atau lebih rendah dari permukaan yang datar dari bendanya. Keduanya mempunyai kekuatan tersendiri yang tentu saja tergantung dari penerapannya terhadap benda yang dihias itu (Toekio,1987:24).

Seni rupa Budha adalah seni yang dipengaruhi oleh nilai-nilai spiritual agama Budha. Seni rupa Budha lahir dalam lingkungan candi atau tempat situs yang menjadi tempat ritual umat Budha seperti relief, candi, wihara, dan arca. Bentuk seni rupa tersebut adalah tokoh agama yaitu Budha dan Budhisatwa atau mengacu pada bentuk simbolis lainnya seperti genta, stupa, mandala, dan wajra. Kelahiran seni Budha lahir dari India, hal ini berdasarkan cerita dari kisah hidup dan perjalanan Siddharta Gautama. Seni rupa tersebut berkembang sesuai dengan ajaran Budha dan penyebarannya sesuai dengan apa yang diajarkan dalam Dharma. Bahkan seni Budha yang berkembang di luar negara India atau Asia penerapannya diadaptasi sedemikian rupa sehingga sesuai dengan kebudayaan masing-masing negara yang mengembangkannya (Widharta, 2014:9).

Stupa adalah sebuah benda atau bangunan suci pada agama Budha. Bentuknya merupakan sebuah bangunan kubah, berdiri di atas sebuah alas (= lapik) dan sebuah tiang puncak di atasnya. Tentang asal mula bentuk stupa itu ada yang meriwayatkan sebagai berikut: tersebutlah dua orang pengikut pertama agama Budha yang diberi tanda mata oleh sang Budha, berupa potongan kuku dan 
rambut serta disuruh menyimpannya dalam stupa. Ketika ditanyakan apakah stupa itu, maka sang Budha membuka pakaiannya, lalu melipatnya menjadi empat persegi dan diletakkan di atas tanah. Sebuah mangkok dalam posisi terlengkup ditaruhnya diatas pakaian itu. Kemudian tongkatnya diletakkan pula diatas mangkok tersebut. Itulah bentuk yang harus diberikan kepada banda yang disebut stupa. Dalam perkembangan agama Budha selanjutnya, bentuk stupa itu ikut berkembang sedemikian rupa, tidak hanya merupakan sebuah benda kecil dan sederhana, tetapi berkembang menjadi sebuah bangunan besar yang dianggap suci. Fungsinya juga berkembang dari tempat penyimpanan benda-benda relik Sang Budha dan Bhiksu terkemuka menjadi benda atau bangunan suci agama Budha (Nazir, 1981:31).

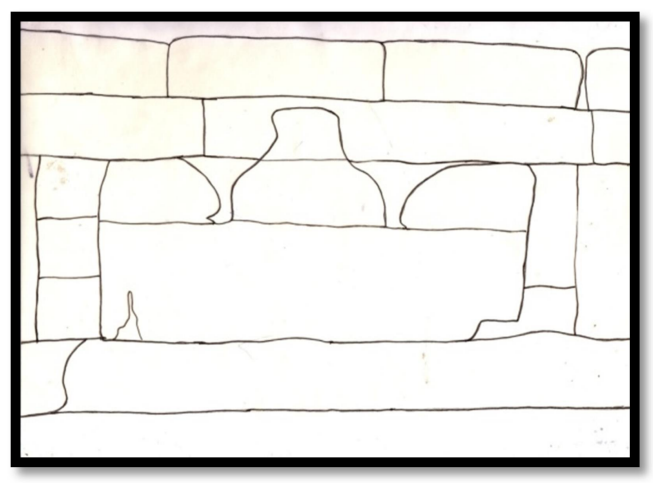

(Gambar: ragam hias yang ditemukan pada gapura Candi Kembar Batu Muara Jambi, sumber hasil gambar Fitria Larasati)

Stupa mempunyai tiga fungsi utama yaitu sebagai relikui yang berisi abu Sang Budha, atau lambang Dharma sebagai tanda peringatan akan tempat terjadinya peristiwa yang berhubungan dengan kehidupan Sang Budha, dan sebagai persembahan. Menurut legenda, ketika Sang Budha memasuki parinirwana tubuhnya dikremasi dan abunya dikumpulkan. Ada 8 raja yang saling berebut kepemilikan abu Sang Budha sampai akhirnya seorang pendeta bernama Drona mendamaikan mereka dengan membagi relikui tersebut menjadi 8 bagian. Masing-masing raja kemudian pulang ke negerinya dengan membawa relikui itu dan menempatkannya di dalam sebuah stupa. Drona sendiri juga mendirikan sebuah stupa untuk menyimpan bejana wadah abu. Stupa juga didirikan di tempat-tempat yang berkaitan dengan peristiwa-peristiwa penting dalam hidup Sang Budha. Dalam naskah Mahaparinibanna Sutta disebutkan bahwa Sang Budha telah menetapkan 4 tempat yang harus di kunjungi pengikutnya setelah ia memasuki parinirwana, yaitu tempat kelahirannya, tempat Sang Budha memperoleh pencerahan. Tempat Sang Budha menyampaikan ajarannya yang pertama, dan tempat ia memasuki parinirwana (Wiyoso, 1982:9).

\section{Sumber Pembelajaran Sejarah Tentang Nilai Budaya Bangunan dan Ragam Hias Candi Kembar Batu Muara Jambi di SMA Azharyah Palembang}

Pembelajaran merupakan implementa si kurikulum, tetapi banyak juga yang mengemukakan bahwa pembelajaran itu sendiri merupakan kurikulum sebagai kegiatan. Untuk mewujudkan pembangunan nasional dibidang pendidikan tersebut diperlukan suatu peningkatan dan penyempurnaan penyelenggaraan pendidikan nasional yang disesuaikan dengan perkembangan ilmu pengetahuan dan teknologi, perkembangan masyarakat, tantangan global, serta kebutuhan pembangunan. Karena dalam melaksanakan tugas guru dituntut memiliki keterampilan profesional yang tinggi. Dengan demikian dalam pembelajaran seseorang perlu terlibat dalam refleksi dan penggunaan memori untuk melacak apa saja yang harus ia simpan dalam memorinya dan bagaimana ia menilai informasi yang telah diperoleh (Wiyoso, 1982:2)

Seorang guru wajib memahami materi pelajaran yang akan disampaikan kepada peserta didik saat proses belajar 
berlangsung, akan tetapi sebelumnya harus membuat ringkasan materi sehingga dapat memudahkan guru dalam menyampaikan materi yang akan diajarkan. Memperbanyak membaca merupakan keuntungan tersendiri bagi guru sehingga dapat menambah pengetahuan dan bahan ajar yang disampaikan, Kegiatan pembelajaran di SMA Azharyah Palembang menggunkan buku yang sesuai dengan kurikulum KTSP. buku yang digunakan sebagai bahan ajar adalah buku TUNTAS (tuntunan ke universitas) terbitan Graha Pustaka. (catatan wawancara dengan Ibu Martini, S.Pd pada tanggal 12 Mei 2017 jam 09.00 WIB).

Menurut ibu Martini, S.Pd berdasarkan hasil wawancara pada tanggal 11 Mei 2017 jam 09.00 WIB beliau mengatakan bahwa modul Nilai Budaya Bangunan dan Ragam Hias Candi Kembar Batu Muara Jambi yang dibuat oleh peneliti sudah cukup baik karena modul tersebut dibuat dari hasil penelitian yang telah dilakukan peneliti dan juga modul telah dilengkapi dengan gambar, jurnal, serta sumber buku yang jelas dan sudah lengkap. Sehingga nantinya modul tersebut dapat dijadikan referensi tambahan untuk sumber pembelajaran sejarah khususnya pada materi hasil peninggalan agama Budha yang ada di Indonesia terutama yang terdapat di provinsi Jambi yaitu candi Kembar Batu Muara Jambi dan juga dapat menambah minat siswa dalam belajar sejarah.

Nilai Budaya Bangunan dan Ragam Hias Candi Kembar Batu Muara Jambi Sebagai Sumber Pembelajaran Sejarah di SMA Azharyah Palembang

Nilai Budaya Bangunan dan Ragam Hias Candi Kembar Batu Muara Jambi layak dijadikan sumber pembelajaran karena sesuai dengan silabus dan kurikulum yang berlaku di SMA Azharyah Palembang. Budaya Bangunan dan Ragam Hias Candi Kembar Batu Muara Jambi adalah salah satu contoh peninggalan agama Budha yang berada di Indonesia terutama di daerah Jambi. Sebagai sumber pembelajaran sejarah di SMA Azharyah Palembang Nilai Budaya Bangunan dan Ragam Hias Candi Kembar Batu Muara Jambi terdapat pada Standar Kompetensi 2. Menganalisis Perjalanan Bangsa Indonesia pada Masa Negara-negara Tradisional dan Kompetensi Dasar: 2.2 Mendeskripsikan perkembangan kehidupan masyarakat, pemerintahan dan kebudayaan pada masa Hindu-Buddha serta menunjukan bukti-bukti peninggalannya. Candi Kembar Batu Muara Jambi merupakan hasil peninggalan kebudayaan masyarakat Indonesia terutama agama Budha yang berlangsung ketika masa kerajaan Melayu Kuno dan Sriwijaya, hal ini dibuktikan dengan ditemukannya ragam hias bermotif stupa pada bagian pinggur gapura atau pintu gerbang candi.

Untuk dapat memperoleh data bahwasannya hasil penelitian yang peneliti lakukan berguna dan bermanfaat sebagai sumber pembelajaran sejarah, peneliti melakukan penelitian langsung dengan melakukan wawancara kepada guru sejarah kelas XI di SMA Azharyah Palembang yaitu dengan ibu Martini, S.Pd. Berdasarkan hasil wawancara pada tanggal 11 Mei 2017 jam 09.00 WIB menurut beliau bahwa penggunaan sumber pembelajaran sejarah di SMA Azharyah Palembang khususnya tentang Nilai Budaya Bangunan dan Ragam Hias Candi Kembar Batu Muara Jambi belum pernah dilakukan. Beliau juga mengatakan bahwa materi Nilai Budaya Bangunan dan Ragam Hias Candi Kembar Batu Muara Jambi layak untuk dijadikan sumber pembelajaran sejarah hal tersebut didasari oleh pentingnya memperkenalkan hasil peninggalan-peninggalan masa agama Budha kepada siswa-siswi, khususnya peninggalan candi Kembar Batu Muara Jambi yang terletak di desa Muara Jambi, kecamatan Marosebo, kabupaten Muara Jambi, provinsi Jambi. Dengan adanya pengenalan materi tentang Nilai Budaya Bangunan dan Ragam Hias Candi Kembar 
Batu Muara Jambi sebagai sumber pembelajaran sejarah sehingga dapat mempermudah tenaga pengajar dalam memperkenalkan hasil peninggalanpeninggalan agama Budha yang ada di Indonesia khususnya mengenai Budaya Bangunan dan Ragam Hias Candi Kembar Muara Jambi kepada siswa-siswi sehingga peserta didik dapat mengetahui tentang Nilai Budaya Bangunan dan Ragam Hias Candi Kembar Muara Jambi.

\section{SIMPULAN}

Berdasarkan uraian dari bab-bab terdahulu, penulis mengambil kesimpulan bahwa :

Situs Muara Jambi terletak di Desa Muara Jambi, Kecamatan Marosebo, Kabupaten Muara Jambi. Situs Muara Jambi ini Adalah sebuah situs kompleks percandian yang merupakan tinggalan kebudayaan klasik masa Sriwijaya dan Melayu Kuno, dengan ditemukannya kompleks percandian Muara Jambi ini maka dapat dikatakan bahwa wilayah percandian ini dulunya pernah menjadi tempat tinggal permanen masyarakat terdahulu. Banyak sekali peninggalan-peninggalan yang ditemukan di situs percandian Muara Jambi ini seperti mata uang china, kanal-kanal kuno, potongan-potongan keramik, manik-manik dan patung. Sampai saat ini bangunan candi yang telah berhasil ditemukan berjumlah sebelas candi termasuk diantaranya adalah kompleks percandian Kembar Batu yang memiliki luas 6.158 meter persegi dengan ketinggian 2,5 sampai 3 meter.

Situs percandian Kembar Batu Muara Jambi merupakan komplek percandian yang terdiri dari 1 candi induk, 6 perwara, struktur bangunan satu dan dua, pagar keliling, 1 gapura, dan parit yang mengelilingi candi. Pada kompleks candi Kembar Batu sendiri pernah ditemukan gong yang terbuat dari bahan perunggu di bagian sisi selatan tangga bangunan induk dan sekarang gong DAFTAR PUSTAKA tersebut tersimpan di Museum Negeri Jambi, selain gong perunggu pada candi Kembar Batu ini juga pernah ditemukan lempengan emas dan batu-batu akik, manikmanik yang terbuat dari batu dan kaca, serta keramik asing yang berasal dari dinasti Sung (abad 10-12 M).

Nilai budaya pada bangunan candi Kembar Batu Muara Jambi terletak pada fungsi candi itu sendiri yang mana candi dalam bahasa Sansekerta adalah sebutan untuk Durga atau dewi maut candika, Candi kemudian dikaitkan dengan bangunan kematian atau pemujaan arwah, sedangkan dalam pemahaman arkeologi, candi dapat dihubungkan dengan bangunan untuk pemakaman maupun pemujaan.

Sedangkan ragam hias yang terdapat pada candi Kembar Batu sendiri adalah adanya relif berbentuk stupa yang terletak pada bagian depan gapura atau pintu gerbang candi. Stupa merupakan salah satu dari objek religius terpenting agama Buddha karena stupa dianggap sebagai gambaram makrokosmos yang berkaitan dengan sang Buddha. Stupa sendiri memiliki tiga fungsi utama yaitu sebagai tempat penyimpanan abu seorang yang suci dalam kepercayaan Buddha, sebagai lambang dharma tanda peringatan tempat terjadinya peristiwa penting yang berhubungan dengan sang Buddha, dan yang teraghir yaitu sebagai tempat persembahan.

Nilai budaya banguna dan ragam hias candi Kembar Batu Muara Jambi dapat dijadikan sebagai sumber pembelajaran sejarah di kelas XI SMA Azharyah Palembang, karena nilai budaya bangunan dan ragam hias pada candi Kembar Batu Muara Jambi belum pernah diterapkan sebagai sumber pembelajaran oleh guru mata pelajaran khususnya sejarah. dengan adanya materi ini diharapkan dapat menembah pengetahuan tentang nilai budaya bangunan dan ragam hias khususnya pada candi Kembar Batu Muara Jambi. 
Mundardjito. 2009. Muara Jambi Dulu, Sekarang, dan Esok. Palembang: Balai Arkeologi Palembang.

Nazir. 1981. Arkeologi Klasik Daerah Jambi. Jambi: Departemen Pendidikan dan Kebudayaan Provinsi Jambi.

Sugiyono. 2008. Memahami Penelitian Kualitatif. Bandung: Alfabeta.

Toekio, Sugeng M. 1987. Mengenal Ragam Hias Indonesia. Ba ndung: Angkasa.

Utomo, Budi Bambang. 2011. Kebudayaan Zaman Klasik Indonesia di Batanghari. Jambi: Dinas Kebudayaan dan Pariwisata Provinsi Jambi.

Purwanti, Retno. 2009. Muaro Jambi Duli, Sekarang Dan Esok. Palembang: Balai Arkeologi Palembang.

Wiyoso. 1982. Album Seni Budaya Jambi Cultural Album Of Jambi.

Widharta, Elyandra. 2014. Pengetahuan Seni Rupa Asia. Yogyakarta: Taka Publisher. 